\title{
Natural Inhibitors of Tumour Necrosis Factor- $\alpha$ Production, Secretion and Function
}

\author{
Solomon Habtemariam \\ School of Chemical and Life Sciences, The University of Greenwich, London, UK
}

Received: September 30, 1999; Accepted: January 23, 2000

\begin{abstract}
Tumour necrosis factor- $\alpha$ (TNF), originally discovered by its antitumor activity, is one of the most pleotropic cytokines acting as a host defence factor in immunologic and inflammatory responses. Although the antitumour activity and mediation of inflammation by TNF could be beneficial to the host, unregulated TNF is now known to be the basis for development of various diseases including septic shock, the wasting disease, cachexia, and various inflammatory and/or autoimmune diseases. With an attempt to find potential therapeutic agents for TNF-mediated diseases, research during the last decade has led in the identification of well over one hundred natural inhibitors of either TNF production/secretion or function. This review summarises the structures, mechanism of action and therapeutic potential of these natural products.
\end{abstract}

Key words: TNF, natural inhibitors, adhesion molecules, NF- $\kappa \mathrm{B}$, cAMP, inflammation, cytotoxicity.

\section{Introduction}

Tumour necrosis factor- $\alpha$ (TNF; also known as cachectin) was originally discovered by its antitumour activity, but it is now recognised to be one of the most pleotropic cytokines acting as a host defence factor in immunologic and inflammatory responses (1), (2). Among its many different activities, TNF has effects on the vascular endothelium which leads to upregulation of various cell adhesion molecules such as intercellular adhesion molecule-1 (ICAM-1), vascular cell adhesion molecule-1 (VCAM-1) and endothelial-leucocyte adhesion molecule-1 (ELAM-1) (3). The regulated expression of these adhesion molecules and their counter-receptors on leucocytes mediates the adhesion and extravasation of white blood cells during inflammatory reaction. While mediation of inflammation and anti-tumour activity by TNF could be beneficial to the host, overproduction of TNF is the basis for the development of various diseases. There is now overwhelming evidence to suggest that TNF mediates the wasting disease, cachexia, associated with chronic diseases such as cancer and AIDS (4), (5). TNF also plays pivotal roles in the development of pathologies such as disseminated intravascular coagulation

Planta Medica 66 (2000) 303-313

(c) Georg Thieme Verlag Stuttgart · New York ISSN: 0032-0943 and death in septic shock and cerebral malaria (6), (7) and a range of inflammatory diseases including asthma (8) and dermatitis, multiple sclerosis, inflammatory bowel disease, cystic fibrosis, rheumatoid arthritis, multiple sclerosis and immunological diseases (9). It is thus clear that suppression of TNF production/release or inhibition of its function could benefit in the treatment of these TNF-mediated diseases.

\section{Potential Targets for Natural Products}

The various target sites for modulation of TNF production and function by antibodies and pharmacological agents have been reviewed recently (9), (10). Potential target sites for inhibitory small molecular weight natural products could be broadly divided into three areas: i) inhibition of TNF production and secretion, ii) TNF receptor antagonism, and iii) inhibition of TNF function through modulation of its signal transduction pathway(s). During the 1990's, research in our laboratories and many others world-wide has identified a number of anti-TNF natural products belonging to various structural groups. In this article, the structures and biological activities of these natural anti-TNF compounds are systematically reviewed with reference to the above three modes/sites of action.

\section{Inhibition of TNF Production and Secretion}

Monocytes and macrophages are the principal TNF factories in the body but it has now emerged that other cell types including T lymphocytes, mast cells, neutrophils, keratinocytes, astrocytes, microglial cells, smooth muscle cells and many others are known to produce TNF. The induced (e.g., by bacterial endotoxins and proinflammatory cytokines) release of TNF from most of these cells requires de novo protein synthesis which can be targeted by drugs at transcriptional, translational and post-translational levels. A large number of natural anti-TNF compounds reviewed in this article act through this mode of action. Most of these bioactive compounds were assessed in vitro by using culture of either monocytes/macrophages isolated from human peripheral blood (11-13); alveolar macrophages (12) or most commonly thioglycolate-elicited peritoneal macrophages from experimental animals (mice or rats) (14-17) or established monocyte/macrophage cell lines such as RAW 264.7 cells (18-20). Treatment of monocytes/macrophages for 6-24 hours with proinflammatory agents, but most commonly with lipopolysac- 
charide (LPS; E. coli endotoxin, $10 \mathrm{ng} / \mathrm{ml}-10 \mu \mathrm{g} / \mathrm{ml}$ ), results in substantial amount of TNF release which can be quantified by either ELISA (19-21) or using TNF-sensitive target cells such as L929 cells (14), (16), (18). Similarly, the effects of compounds on TNF production in vivo is commonly studied by administering LPS in experimental animals such as mice (about $100 \mu \mathrm{g} /$ mouse) and monitoring the level of TNF as described above.

It is now well established that one crucial step in the transcriptional activation of TNF gene is the transcription factor, nuclear factor $\kappa \mathrm{B}(\mathrm{NF}-\kappa \mathrm{B})$ mobilisation (22). NF- $\kappa \mathrm{B}$ is sequestered in the cytoplasm by inhibitory proteins $\mathrm{I} \kappa \mathrm{B}$, which are phosphorylated by a cellular kinase leading to degradation and translocation of NF- $\kappa$ B to the nucleus (23). The potential target of NF- $\kappa \mathrm{B}$ in TNF-mediated diseases is evident as inappropriate regulation of NF- $\kappa \mathrm{B}$ has been shown to be associated with diseases such as septic shock, graft versus host reaction, acute inflammatory condition, acute phase response, radiation damage, atherosclerosis and cancer (24). Of the known natural inhibitors of TNF production (see also Figs. 1 and 2 ), the two classical anti-inflammatory agents, aspirin and salicylic acid, have been shown to act in vitro through inhibition of $\mathrm{I} \kappa \mathrm{B}$ degradation and the subsequent inhibition of $N F-\kappa B$ activation (25), (26). Other anti-inflammatory agents reported for inhibition (at $\mu \mathrm{M}$ concentration range) of NF- $\kappa \mathrm{B}$ activation and the subsequent TNF release include resveratrol (1) and quercetin (19), (21), (27), nordihydroguaiaretic acid (2), butylated hydroxyanisol and tetrahydropapaveralione (6) (11), curcumin (3) (12), (28), myricetin (27), epigallocatechingallate (29), 4-hydroxy-2-nonenal (30), and capsaicin (7) (31). In experiments using BALB/c mice, however, dietary capsaicin (7) did not show the expected immunosuppression and a rather high level of TNF was detected following capsaicin (7) feeding suggesting possible enhancement of the immune functions (32). Large doses ( $\mu \mathrm{M}$ concentration) of morphine have also been shown to suppress NF- $\kappa \mathrm{B}$ activation and TNF release both in vitro and in vivo (33), (34). This effect of morphine is in agreement with a high incidence of immunosuppression in opioid addicts (33). Other important observations related to immunosuppression were those of nicotine (maximum effect at $10 \mathrm{nM}$ ) and cigarette smoking, both of which were reported to suppress TNF release in vitro through inhibition of NF- $\kappa$ B mobilisation (35), (36). The other constituent of cigarette smoke is hydroquinone which is also known to suppress NF- $\kappa$ B activation (37).

Elevation of the intracellular cyclic adenosine 3',5'-monophosphate (cAMP) level in monocytes/macrophages and many other cell types results in inhibition of TNF release and downregulation of the immune response (38). Intracellular cAMP levels can be elevated by activation of cAMP-generating adenylate cyclase $(\mathrm{AC})$. Thus, prostaglandin $\mathrm{E}_{2}\left(\mathrm{PGE}_{2}\right)$ that elevates CAMP through action resulting in the activation of $A C$ has been shown to suppress TNF release in vitro and protects animals from septic shock (39). As expected, forskolin (74, at concentrations less than $10 \mu \mathrm{M})$, a direct activator of $\mathrm{AC}$, has been shown to inhibit TNF production in various cell types (40 and references therein). Another means of elevating cAMP is through inhibition of cAMP cleavage by phosphodiesterase (PDE) enzymes. PDE type IV has been identified to be the major isoform in the catabolism of cAMP in inflammatory functions in various blood cells (41). While several synthetic PDE
IV inhibitors have been demonstrated to suppress TNF release in vitro and inflammation in vivo (9), (10), not many natural products have been identified with a similar mechanism. One natural product, theophylline with non-selective action on PDE inhibition has been demonstrated to suppress TNF release but its clinical use is limited due to its weak effect and narrow therapeutic window (42). A very recent work on biological activity studies of citrus flavonoids revealed that several polymethoxylated flavonoids (19-29) potently inhibited (with $\mathrm{IC}_{50}$ values between 5 and $30 \mu \mathrm{M}$ ) the release of TNF from monocytes in vitro (Table 1) (43). The further demonstration of PDE IV inhibition associated with a high level of intracellular cAMP following treatment of cells by these compounds (43) established their possible mechanism of action, although other effects could not be ruled out.

Although the underlying mechanism has not yet been clearly established, many other natural products have been shown to inhibit TNF production (see also Fig. 2). These include the antipsoriatic phenolic compound, anthraline (30) (13); lignans woorenosides II-V (31-34), lariciresinol glycoside (35) and pinoresinol (36) (44) and eudesmin (37) and to some extent magnolin (38) and lirioresinol-B dimethyl ether (39) (45); flavonoids - naringin (46), epicatechin (47), some isoprenoidsubstituted flavones of Artocarpus spp., namely, heterophyllin (42), artonin E (43), artobiloxanthone (44), cycloartobiloxanthone (45), cycloheterophyllin (46) and morusin (47) (48), and silymarin (49) which is known to be a mixture of silydianin and silibinin; alkaloids - anisodamine (48) (39), (50), quinine (at concentrations that block potassium channels) (51), fangchinoline (49) and isotetrandrine (50) (52) and colchicine (51) (14), (53); terpenoids - cynaropicrin (54), reynosin (55) and santamarin (56) (64) and dehydrocostus lactone (53) (20) and the anti-inflammatory saponin, esculentoside A (57) (15), both of which have also been shown to suppress the serum level of TNF in vivo; long chain fatty acids - $\omega$-fatty acids of fish oil origin, docoshexaenoic acid (DHA) and eicosahexaenoic acid (EPA) but also to some extent saturated fatty acids, stearic acid, palmitic acid (55) and anandamide (56). The hepatoprotective compound, tetrahydroswertianolin (40), which inhibits the D-galactoseamine (DGalN)/LPS liver injury in mice has been shown to suppress the serum level of TNF in vivo (57). Of the fungal metabolites, the immunosuppressive agent, cyclosporin A has been demonstrated to suppress TNF production both in vitro and in vivo (58). Another fungal metabolite of interest is trichodimerol (58) (59) as well as tetracycline (60), both of which have been shown to inhibit TNF secretion in vitro. Inhibition of TNF release at higher concentrations ( $\mathrm{mM}$ range) of the antibiotic tetracycline has been shown to be associated with retention of membrane associated TNF (61) suggesting possible metalloproteinase blocking activity. Processing of the TNF precursor (pro-TNF) to mature biologically active TNF by metalloproteinases has been one of the anti-inflammatory target sites for synthetic agents (9), (10). The other possible natural metalloproteinase inhibitor is the immunosuppressive and psychactive agent, $\delta^{9}$-tetrahydrocannabinol (41), which has been reported to inhibit TNF production through action at a posttranscriptional level (62). Other natural products of fungal origin with TNF production inhibitory effects are the antibiotic erythromycin (63), cytochalasin D (52) (16), the toxic metabolite aflatoxin $B_{1}(59)$ (17) and known kinase inhibitors herbimycin A and staurosporin (see below). 


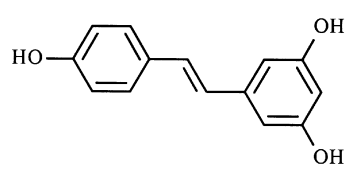

1 resveratrol $\left(>0.1 \mu \mathrm{M}^{\mathrm{a}}\right.$; tested at 50 and $\left.100 \mu \mathrm{M}^{\mathrm{b}}\right)$<smiles>COc1cc(/C=C/C(=O)CC(=O)/C=C/c2ccc(O)c(OC)c2)ccc1O</smiles>

3 curcumin $(0.5-10 \mu \mathrm{M})^{\mathrm{a}, \mathrm{c}-\mathrm{e}}$<smiles>Cc1cc(O)c2c(c1)C(=O)c1cc(O)cc(O)c1C2=O</smiles>

5 emodin $(10-50 \mu \mathrm{g} / \mathrm{ml})^{\mathrm{a}, \mathrm{d}}$<smiles>CC(Cc1ccc(O)c(O)c1)[C@@H](C)Cc1ccc(O)c(O)c1</smiles>

2 nordihydroguaiaretic acid ( $\left.\mathrm{IC}_{50} 2.8 \mu \mathrm{M}\right) \mathrm{c}$<smiles></smiles>

4 hypericin (tested at $2 \mu \mathrm{M})^{\mathrm{f}}$<smiles>Oc1ccc(CC2NCCc3cc(O)c(O)cc32)cc1O</smiles>

6 tetrahydropapaveroline (IC $501.2 \mu \mathrm{M}$ ) $\mathrm{c}$<smiles>NC1=NC(=O)C(=C2CCCNC(=O)c3[nH]c(Br)cc32)N1</smiles>

8 hymenialdisine $(0.1-10 \mu \mathrm{M})^{\mathrm{h}}$

Fig. 1 Structure and activity of some inhibitors of TNF production/function in vitro: Inhibitors of NF- $\kappa B$ mobilisation (1-18).

a Adhesion molecules expression (12), (19), (21), (75), (88), (94).

b TNF release from Kupffer cells (23) and RAW 264.7 macrophages (19).

c TNF release from peripheral blood mononuclear cells (11), (12).

d Monocyte-endothelial cell adhesion (88), (94).

e Endothelial tissue factor expression $\left(\mathrm{IC}_{50}\right.$ $5 \mu \mathrm{M})(101)$.

$\mathrm{f}$ IL-6 production in stably transfected HeLa cells (97).

$9 \mathrm{NF}-\kappa \mathrm{B}$ activation in human ML-1a cells (31), (105).

h IL-8 production by U937 cells (98).

i Enhance TNF cytotoxicity in L929 cells (75).

j Total inhibition of NF- $\kappa$ B activation in Jurkat cells (99), (106).<smiles>COc1cc(CNC(=O)CCCC/C=C/C(C)C)ccc1O</smiles>

7 capsaicin $(100-300 \mu \mathrm{M}) \mathrm{g}$

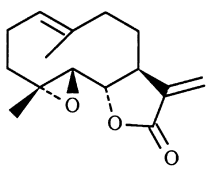

10 parthenolide $(>5 \mu \mathrm{M})^{\mathrm{a}, \mathrm{i}}$

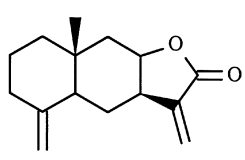

11 isohelenin $(>10 \mu \mathrm{M})^{\mathrm{a}, \mathrm{i}}$<smiles>C=C1C(=O)O[C@H]2CCC(C)[C@H]3C=CC(=O)[C@@]3(C)[C@H](O)[C@H]12</smiles>

$12 \mathrm{R}=\mathrm{OH}$ Helenalin $(10 \mu \mathrm{M}) \mathrm{j}$

$13 \mathrm{R}=\mathrm{O}-\mathrm{COCH}\left(\mathrm{CH}_{3}\right)_{2}$ helenalin isobutyrate $(20 \mu \mathrm{M}) \mathrm{j}$
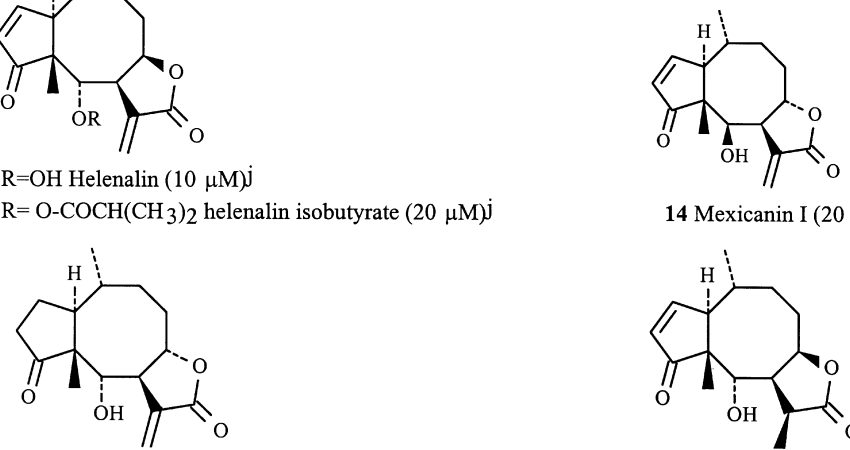

15 2,3-dihydroaromaticin $(50 \mu \mathrm{M})$

$$
14 \text { Mexicanin I }(20 \mu \mathrm{M}) \mathrm{j}
$$

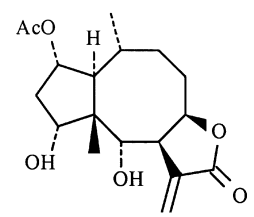

17 chamissonolide $(200 \mu \mathrm{M})$

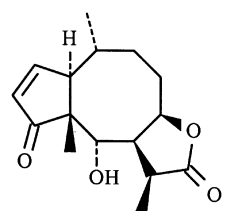

$1611 \alpha, 13$-dihydrohelenalin $(200 \mu \mathrm{M}) \mathrm{j}$

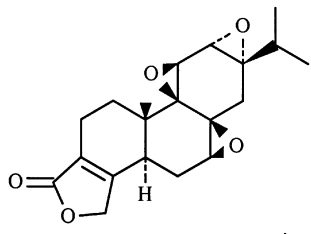

18 triptolide $(1 \mu \mathrm{g} / \mathrm{ml}) \mathrm{j}$ 
Table 1 Biological activity of Citrus flavonoids.<smiles>[R]c1cc(-c2oc3c([2H])c([R3])c([R])c([R])c3c(=O)c2[R])cc([R])c1OC</smiles>

\begin{tabular}{l|llllllll}
\hline & $\mathrm{R}^{1}$ & $\mathrm{R}^{2}$ & $\mathrm{R}^{3}$ & $\mathrm{R}^{4}$ & $\mathrm{R}^{5}$ & $\mathrm{R}^{6}$ & $\mathrm{R}^{7}$ & $\mathrm{IC}_{50}, \mu \mathrm{M}^{*}$ \\
\hline $\mathbf{1 9}$ & $\mathrm{H}$ & $\mathrm{OMe}$ & $\mathrm{OMe}$ & $\mathrm{OMe}$ & $\mathrm{H}$ & $\mathrm{H}$ & $\mathrm{H}$ & 22 \\
$\mathbf{2 0}$ (tangeretin) & $\mathrm{H}$ & $\mathrm{OMe}$ & $\mathrm{OMe}$ & $\mathrm{OMe}$ & $\mathrm{OMe}$ & $\mathrm{H}$ & $\mathrm{H}$ & 30 \\
$\mathbf{2 1}$ & $\mathrm{OMe}$ & $\mathrm{OMe}$ & $\mathrm{OMe}$ & $\mathrm{OMe}$ & $\mathrm{OMe}$ & $\mathrm{OMe}$ & $\mathrm{H}$ & 5 \\
$\mathbf{2 2}$ (nobiletin) & $\mathrm{H}$ & $\mathrm{OMe}$ & $\mathrm{OMe}$ & $\mathrm{OMe}$ & $\mathrm{OMe}$ & $\mathrm{OMe}$ & $\mathrm{H}$ & 10 \\
$\mathbf{2 3}$ (sinensetin) & $\mathrm{H}$ & $\mathrm{OMe}$ & $\mathrm{OMe}$ & $\mathrm{OMe}$ & $\mathrm{H}$ & $\mathrm{OMe}$ & $\mathrm{H}$ & 8 \\
$\mathbf{2 4}$ & $\mathrm{H}$ & $\mathrm{OH}$ & $\mathrm{OMe}$ & $\mathrm{OMe}$ & $\mathrm{OMe}$ & $\mathrm{OMe}$ & $\mathrm{H}$ & 5 \\
$\mathbf{2 5}$ & $\mathrm{H}$ & $\mathrm{OMe}$ & $\mathrm{H}$ & $\mathrm{OMe}$ & $\mathrm{OMe}$ & $\mathrm{OMe}$ & $\mathrm{H}$ & 16 \\
$\mathbf{2 6}$ & $\mathrm{OMe}$ & $\mathrm{OMe}$ & $\mathrm{OMe}$ & $\mathrm{OH}$ & $\mathrm{OMe}$ & $\mathrm{OMe}$ & $\mathrm{H}$ & 22 \\
$\mathbf{2 7}$ & $\mathrm{OMe}$ & $\mathrm{OH}$ & $\mathrm{OMe}$ & $\mathrm{OMe}$ & $\mathrm{OMe}$ & $\mathrm{OMe}$ & $\mathrm{H}$ & 10 \\
$\mathbf{2 8}$ & $\mathrm{H}$ & $\mathrm{OMe}$ & $\mathrm{OMe}$ & $\mathrm{OMe}$ & $\mathrm{H}$ & $\mathrm{OMe}$ & $\mathrm{OMe}$ & 20 \\
$\mathbf{2 9}$ & $\mathrm{H}$ & $\mathrm{OMe}$ & $\mathrm{OMe}$ & $\mathrm{H}$ & $\mathrm{H}$ & $\mathrm{OMe}$ & $\mathrm{H}$ & 25 \\
\multicolumn{2}{|l}{ *effects of intracellular cAMP elevating flavonoids on LPS $(10 \mathrm{ng} / \mathrm{ml}$ )-stimulated }
\end{tabular}

$\mathrm{TNF}$ release from human peripheral blood monocytes in vitro (43).

In some instances, the ubiquitous biological activities displayed by some compounds, for example, non-selective inhibition of various enzymes including kinases, inhibition of tyrosine phosphorylation and inositol phosphate metabolism displayed by polyphenols [flavonoids, curcumin (3), etc.] and these often seen in combination with antioxidant activity, made it difficult to pinpoint the exact mechanism of action of compounds. It is also worth noting that protein tyrosine kinase activity has been demonstrated to be essential for the activation of NF- $\kappa$ B by various agents and thus inhibition of TNF release by kinase inhibitors is expected (22), (64). For example, the well known natural protein tyrosin kinase (PTK) inhibitors, genistein and herbimycin A (65), (66) and a non-selective kinase inhibitor, staurosporine (22), have been shown to inhibit TNF production both in vitro and in vivo.

\section{TNF Receptor Antagonists}

As with other protein mediators, the binding surface between TNF and its protein receptors (TNF-R55 and TNF-R75) is expected to be large making it difficult to find a small molecular weight receptor antagonist. Since only a few complementary amino acids have been shown to be critical for TNF activity (67), small molecular weight receptor antagonists, though not available at the moment, could still be the ultimate goal of the TNF-based therapies.

\section{Inhibition of TNF Function}

\section{Inhibitors of TNF-mediated cytotoxicity}

While TNF toxicity to tumour cells and augmentation of this effect by drugs could be beneficial, the unwanted systemic cytotoxicity of TNF associated with various diseases needs to be modulated. As with TNF release, the cytotoxic response of TNF could be targeted at the various levels of TNF signalling. Experimentally, potential inhibitors of TNF-cytotoxicity could easily be studied using TNF-sensitive cell lines including by far the most commonly used, L929 cells (68-70). In the presence of protein synthesis inhibitors such as actinomycin $D$ (usually $2 \mu \mathrm{g} / \mathrm{ml}$ ), TNF induces DNA fragmentation within 6 hours followed by cell death within 24 hours. Based on this
L929 cell-based bioassay, a number of phenolic compounds (3,4-dihydroxybenzoic acid and caffeic acid and also neurotransmitters dopamine and noradrenaline) which possess the catecholic functional moiety have been shown to suppress TNF cytotoxicity (68). These effects of catechols [including that of nordihydroguaiaretic acid (2)] are not related to their antioxidant action as related antioxidants failed to protect cells from TNF cytotoxicty (68). Further studies on the mechanism of action of catechols revealed that inhibition of TNF cytotoxicity by catechols is related to their iron chelating activity and the subsequent inhibition of lipoxygenase enzymes (68), (69). On the basis of these findings, large numbers of flavonoids were tested for their inhibitory effect on TNF cytotoxicity in vitro (70). It appears that all flavonols tested (galangin, kaempferol, kaempferide, quercetin, myricetin, morin and rutin) inhibited TNF cytotoxicity and the C-3 free hydroxy group of these structural groups appears to play a pivotal role in the observed protective effect. In contrast to this protective effect of flavonols, no protective activity was observed for the flavones (chrysin, apigenin and luteolin) tested. In fact, apigenin and chrysin which possess one (C-4 ) hydroxy group or none on the B-ring, respectively, enhanced the TNF cytotoxicity (70). Epicatechin and flavanones which bears the catecholid functional moiety (eriodictyol and taxifolin) were protective while other flavanones without this o-dihydroxy functionality either failed to protect (pinocembrin, isosakuranetin, hesperetin) or enhanced (naringenin) the TNF cytotoxicty (70). It is worth noting that all protective flavonoids and other catecholic compounds were effective when they were added as post-TNF treatment (70). As some of the flavonoids showed enhancement of the TNF cytotoxicity, the clinical use of such compounds for inhibition of TNF cytotoxicity needs detail analysis of their structural moiety ex vivo and in vivo.

Together with activation of various cascades, TNF signalling during induction of cell death is also associated with activation of NF- $\kappa$ B. Unlike the TNF production and action on endothelial cells (see below), however, NF- $\kappa$ B activation by TNF antagonises the TNF cytotoxicity (71), (72). Thus, cells including tumour cells, which are capable of activating their NF- $\kappa$ B during TNF treatment are resistant to TNF cytotoxicity and compounds including salicylic acid (73), curcumin (3) (74), parthenolide (10) and isohelenin (11) (75) as well as morphine (76) which down regulate the TNF-mediated NF- $\kappa$ B activation have been shown to enhance while agents that activate NF- $\kappa B$ inhibit the TNF cytotoxicity $(71-76)$. There are now several reports suggesting that PTK is involved in the pathway leading to NF- $\kappa$ B activation and gene expression by TNF (22). Genistein and herbimycin A could thus inhibit NF- $\kappa$ B mobilisation and subsequently make resistant cells susceptible to TNF cytotoxicity (77). Since PTK and/or NF- $\kappa B$ are linked to diverse biological activities, inhibition of TNF cytotoxicity by activating PTK or NF- $\kappa \mathrm{B}$ is not an attractive therapeutic approach. TNF cytotoxicity is also modulated by cAMP. The induction of TNF cytotoxicity in neutrophils has been shown to be inhibited by cAMP analogues, intracellular cAMP elevating agent, forskolin (74), or phosphodiesterase inhibitors (78).

Other agents that have been reported to inhibit TNF cytotoxicity in vitro, but with as yet unknown mechanism of action (see also Fig. 3) include, butylated hydroxyanisol (79), pyridoxin (80), retinoic acid (vitamin $\mathrm{A}$, both the cis and trans form) and to a lesser extent carotene (81). Two lignanamides, 


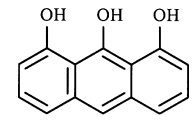

30 anthralin $\left(\mathrm{IC}_{50} 0.3 \mu \mathrm{g} / \mathrm{ml}\right)$

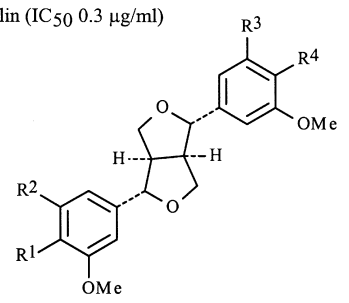

$\begin{array}{llll}\mathrm{R}^{1} & \mathrm{R}^{2} & \mathrm{R}^{3} & \mathrm{R}^{4}\end{array}$

$36 \mathrm{OH} \quad \mathrm{H} \quad \mathrm{H} \quad \mathrm{OH}$ pinoresinol $^{\mathrm{b}}$

$37 \mathrm{OMe} \mathrm{H} \quad \mathrm{H} \quad$ OMe eudesmin $\left(\mathrm{IC}_{50} 51 \mu \mathrm{M}\right)^{\mathrm{c}}$

$38 \mathrm{OMe} \mathrm{OMe} \mathrm{H}$ OMe magnolinc

$39 \mathrm{OMe} \mathrm{OMe} \mathrm{OMe} \mathrm{OMe}$ lirioresinol-B dimethyl ether $\mathrm{C}$

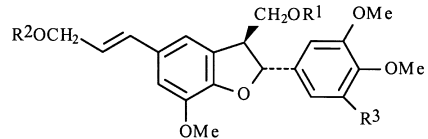

$\begin{array}{lll}\mathrm{R}^{1} & \mathrm{R}^{2} & \mathrm{R}^{3}\end{array}$

$31 \mathrm{Ac}$ Glc OMe woorenoside II $\mathrm{b}$

$32 \mathrm{H} \quad \mathrm{Glc}^{6} \mathrm{~A}$ OMe woorenoside III ${ }^{\mathrm{b}}$

$33 \mathrm{Ac}$ Glc6A OMe woorenoside IV

$34 \mathrm{H}$ Glc6A $\mathrm{H}$ woorenoside $\mathrm{Vb}$

Glc $=\beta$-D-glucopyranosyl

$\mathrm{A}=-\mathrm{CO}-\mathrm{C}\left(=\mathrm{CH}_{2}\right)-\mathrm{CH}_{2} \mathrm{CH}_{2} \mathrm{OH}$<smiles>COc1cc(O)c2c(=O)c3c(oc2c1)[C@H](O)CC[C@H]3O</smiles>

40 tetrahydroswertianolin $(10-200 \mathrm{mg} / \mathrm{kg}) \mathrm{d}$<smiles>COc1cc(C[C@@H]2CO[C@@H](c3ccc(OC)c(OC)c3)[C@H]2C)ccc1O</smiles>

35 lariciresinol glycoside $b$

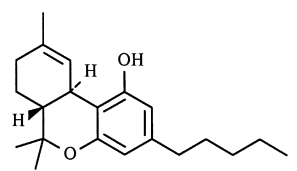

$41 \delta^{9}$-tetrahydrocannabinol $(1-10 \mu \mathrm{g} / \mathrm{ml})$<smiles>CC(C)=CCc1c(-c2cc(O)c(O)cc2O)oc2c(CC=C(C)C)c3c(c(O)c2c1=O)C=CC(C)(C)O3</smiles>

42 heterophyllin $(0.48 \mu \mathrm{M})^{\mathrm{e}}$<smiles>CC(C)=CCc1c2c(c(O)c3c(=O)c4c(oc13)-c1cc(O)c(O)cc1OC4C=C(C)C)C=CC(C)(C)O2</smiles>

46 cycloheterophyllin $(7.8 \mu \mathrm{M})^{\mathrm{e}}$<smiles>COc1ccc(C[C@@H]2Cc3ccc(OC)c(c3)Oc3cc(ccc3OC)C[C@H]3c4c(cc(OC)cc42)CCN3C)cc1</smiles>

50 isotetrandrine $(1-10 \mu \mathrm{g} / \mathrm{ml})$

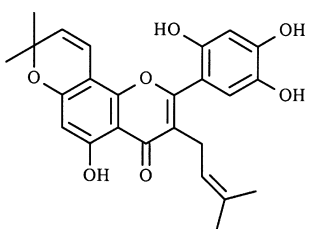

$43 \operatorname{artonin} \mathrm{E}(0.43 \mu \mathrm{M})^{\mathrm{e}}$<smiles>CC(C)=CCc1c(-c2ccc(O)cc2O)oc2c3c(cc(O)c2c1=O)OC(C)(C)C=C3</smiles>

47 morusin $(1.76 \mu \mathrm{M})^{\mathrm{e}}$<smiles>CNC1CCc2cc(OC)c(OC)c(OC)c2-c2ccc(OC)c(=O)cc21</smiles>

51 colchicine $(1-100 \mu \mathrm{M})$<smiles>C=C(C)C1Cc2c(oc3c4c(cc(O)c3c2=O)OC(C)(C)C=C4)-c2c(O)cc(O)c(O)c21</smiles>

44 artobiloxanthone $(0.94 \mu \mathrm{M})^{\mathrm{e}}$

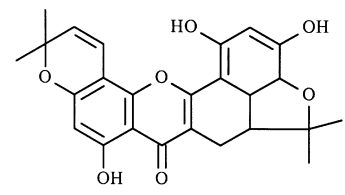

45 cycloartobiloxanthone $(1.94 \mu \mathrm{M})^{\mathrm{e}}$

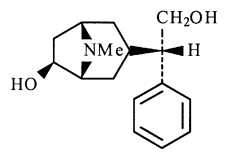

48 anisodamine $(10 \mathrm{mg} / \mathrm{kg})^{\mathrm{f}}$

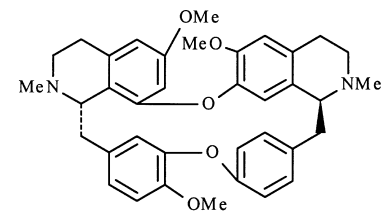

49 fangchinoline $(1-10 \mu \mathrm{g} / \mathrm{ml})$

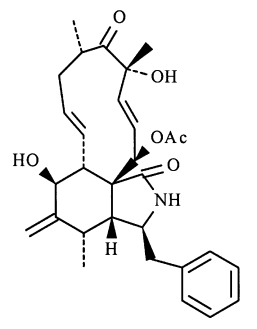

52 cytochalasin D (tested at $0.5 \mu \mathrm{M}$ )

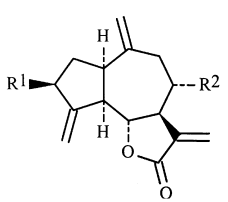

$\mathrm{R}^{1} \mathrm{R}^{2}$

$53 \mathrm{H} \quad \mathrm{H}$ dehydrocostus lactone $\left(0.6-10 \mu \mathrm{M} ; 50 \mathrm{mg} / \mathrm{kg}^{\mathrm{d}}\right)$ $54 \mathrm{OH} \quad \mathrm{OCOC}\left(\mathrm{CH}_{2}\right) \mathrm{CH}_{2} \mathrm{OH}$ cynaropicrin $\left(\mathrm{IC}_{50} 8.24 \mu \mathrm{M}\right)$

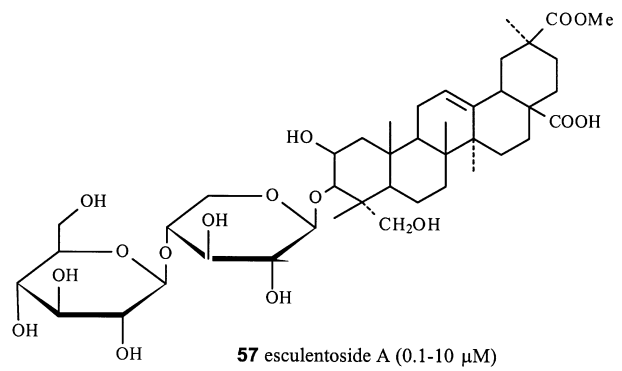

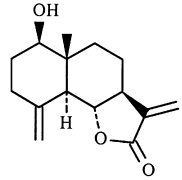

55 reynosin $\left(\mathrm{IC}_{50} 87.4 \mu \mathrm{M}\right)$

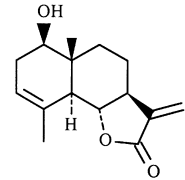

56 santamarin $\left(\mathrm{IC}_{50} 105 \mu \mathrm{M}\right)$

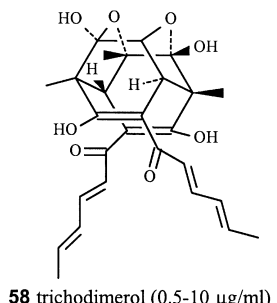

Fig. 2 Structures and activity of some inhibitors of TNF production through as yet unknown mechanism (30-59). ${ }^{a}$ LPS-induced TNF release

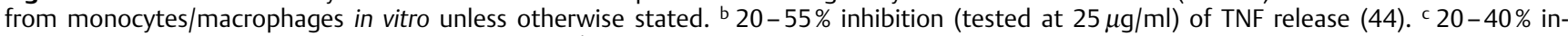
hibition (tested at $12.5 \mu \mathrm{g} / \mathrm{ml}$ ) of TNF release (45). ${ }^{d}$ Effects on LPS-mediated increase in serum level of TNF in mice (57). ${ }^{\text {I IC }}{ }_{50}$ values for inhibiting okadaic acid-induced TNF release from BALB/3T3 cells (48). ${ }^{\mathrm{f}}$ Inhibition of LPS-mediated increase in TNF mRNA in rats (39). 
<smiles>COc1cc(C2Oc3c(OC)cc(/C=C/C(=O)NCCc4ccc(O)cc4)cc3C2C(=O)NCC(=O)c2ccc(O)cc2)ccc1O</smiles>

$60 \mathrm{R}=\mathrm{H}_{2}$ tribulusamide $\mathrm{A}(1-20 \mu \mathrm{M})^{\mathrm{a}}$ $61 \mathrm{R}=\mathrm{O}$ tribulusamide $\mathrm{B}(10-50 \mu \mathrm{M})^{\mathrm{a}}$

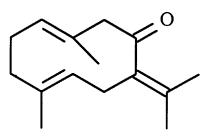

65 germacrone $^{b}$<smiles>C=C[C@H]1C2=CCOC(=O)C2=CO[C@@H]1O</smiles>

69 gentiopicrosidec

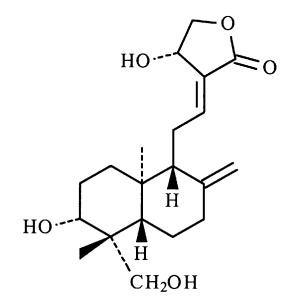

71 andrographolide<smiles>CC(C)=CC[C@@H](O)C1=CC(=O)c2c(O)ccc(O)c2C1=O</smiles>

73 shikonin<smiles>C=C[C@H]1[C@H](OC(C)=O)OC=C2C(=O)OCC[C@@]21C</smiles><smiles>[R1]c1cc(/C=C/C(=O)NCC(=[R2])c2ccc(O)cc2)ccc1O</smiles>

$R^{1} \quad R^{2}$

$62 \mathrm{OMe} \mathrm{H}_{2}(50-200 \mu \mathrm{M})^{\mathrm{a}}$

63 OMe $\mathrm{O} \quad(50-200 \mu \mathrm{M})^{\mathrm{a}}$

$64 \mathrm{H} \quad \mathrm{H}_{2} \quad(50-200 \mu \mathrm{M})^{\mathrm{a}}$

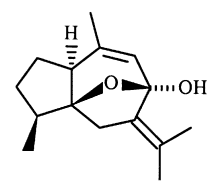

68 curcumenol $^{b}$

$66 \mathrm{R}=\alpha$ Me neocurdione ${ }^{\mathrm{b}}$

$67 \mathrm{R}=\beta \mathrm{Me}$ curdione $\mathrm{b}$

Fig. 3 Compounds with inhibitory effect on TNF toxicity in liver cells (60-70).

a Inhibitory effects (IC $\mathrm{IC}_{50}$ values) on TNF cyto-

toxicity in DGalN-sensitised cultured mouse hepatocytes (82).

b Over $50 \%$ inhibition (at a dose of $50 \mathrm{mg} /$ $\mathrm{kg}$, p.o.) of liver injury in mice induced by TNF $(10 \mu \mathrm{g} / \mathrm{kg})$ and DGalN $(350 \mathrm{mg} / \mathrm{kg})$ (83).

c Effect on LPS/DGalN-induced liver injury in mice (83), (84).<smiles>Oc1ccc(C#CC/C=C/c2ccc(O)c(O)c2)cc1O</smiles>

72 rooperol<smiles>C=C[C@]1(C)CC(=O)[C@]2(O)[C@@H](O1)[C@H](O)C1C(C)(C)CCC(O)[C@@]12C</smiles>

74 forskolin tribulusamides A (60) and B (61) and to a less extent compounds 62-64 have been shown to inhibit the TNF cytotoxicity in DGalN-sensitised cultured mouse hepatocytes (82) while sesquiterpene lactones germacrone $(\mathbf{6 5})$, neocurdione $(\mathbf{6 6})$, curdione (67) and curcumenol (68) have been reported to inhibit in vivo liver injury induced by co-administration of TNF and DGalN (83). These latter compounds (83) as well as gentiopicroside (69) and sweroside (70) (84) have also been shown to inhibit the endotoxin/DGalN-induced liver injury in vivo, which is now known to be TNF-dependent (85). Whether the compounds act through direct inhibition fo the TNF-induced cytotoxicity in liver cells, however, remains to be proved.

Inhibitors of TNF-mediated protein expression and endothelialleucocyte adhesion

The TNF-mediated expression of endothelial cell adhesion molecules (mainly ICAM-1, VCAM-1 and ELAM-1) has been the focus of therapeutic targets in the last decade. Endothelial cell adhesion molecules expression and leucocyte-endothelial cell adhesion have been studied mainly by culturing human umbilical cord endothelial cells and leucocyte sub-populations freshly isolated from human peripheral blood (86-90). The recently characterised endothelial cell lines including EAhy 926 and ECV304 cells together with established monocytic (e.g., U937, HL60 cells) and other cell lines are now routinely used in cell adhesion and adhesion molecules expression studies (18), (27), (88-91 and references therein).

Upregulation of many endothelial cell surface adhesion molecules by TNF involves de novo protein synthesis requiring the activation of NF- $\kappa \mathrm{B}$ (92). By inhibiting this key activation process, salicylic acid (93), gallates (methyl, ethyl, propyl and octyl gallates) (87), emodin (5) (88), curcumin (3) (94) and epigenin (95) treatments of endothelial cells have been shown to suppress the TNF-mediated expression of ICAM- 1 , 
VCAM-1 and ELAM-1 and also endothelial-leucocyte adhesions in vitro. In contrast, another NF- $\kappa B$ mobilisation and endothelial-monocyte adhesion inhibitor, aspirin, inhibits the TNF-mediated induction of VCAM- 1 and ELAM- 1 without altering the ICAM-1 level on endothelial cell surfaces (89). Sesquiterpene lactones, such as parthenolide $(\mathbf{1 0})$ and isohelenin (11) (75) as well as several flavonoids (acetin, bicalein, chrysin, chrysoeriol, kaempferol, luteolin and quercetin; $\mathrm{IC}_{50} 25-$ $50 \mu \mathrm{M})(95)$ have been shown to inhibit NF- $\kappa \mathrm{B}$ mobilisation and the subsequent expression of ICAM-1. Inhibition of NF- $\kappa B$ activation has also been shown to account for the in vitro inhibition of TNF-mediated cytokine production by curcumin (3) (96), hypericin (4) (97), hymenialdisine (8) (98) and triptolide (18) (99); inhibition of monocyte chemoattractant protein expression by quercetin (100) and endothelial-monocyte adhesion inhibitory effect of myricetin (30 and $50 \mu \mathrm{M}$ ) and other weakly active antioxidants [genistein, resveratrol (1) and quercetin] (27). In addition to inhibition of NF- $\kappa$ B activation, curcumin (3) has been reported to inhibit the transcription factor AP-1 thereby suppressing the expression of a coagulation mediator, endothelial tissue factor (101). Other natural NF- $\kappa \mathrm{B}$ mobilisation inhibitors of anti-TNF compounds include DHA and EPA (both tested at $50 \mu \mathrm{g} / \mathrm{ml}$ ) which have been shown to selectively suppress the TNF-induced expression of VCAM-1 (with little effect on the level of ICAM-1 and ELAM1) and lymphocyte-endothelial cell adhesion (102). In contrast, the monounsaturated fatty acid, oleic acid, suppresses the above three adhesion molecules equally (103). DHA is also known to suppress the TNF-mediated cytokines production in monocytes (104). TNF-mediated NF- $\kappa B$ activation inhibitory effect of sanguinarine $(\mathbf{9})$ (105) has recently been reported. It remains to be proved, however, whether the compound inhibits the TNF-induced gene/protein expression. It is interesting to note that, unlike the sesquiterpene lactones parthenolide (10) and isohelenin (11) which have been reported to inhibit TNF function through inhibition of I $\kappa$ B phosphorylation (75), similar compounds 12-17 (Fig. 1) have recently been shown to act through direct alkylation of the activated NF- $\mathrm{B}$ (106).

As discussed above, PTK is involved in the pathway leading to $\mathrm{NF}-\kappa \mathrm{B}$ activation and the subsequent gene expression by TNF (64). Genistein $(10-100 \mu \mathrm{M})$ and herbimycin $\mathrm{A}(0.1-1 \mu \mathrm{M})$, have thus been demonstrated to suppress the TNF-mediated ICAM-1, VCAM-1 and ELAM-1 expression on endothelial cells and the subsequent monocyte-endothelial adhesion (107), (108). Plasminogen activator inhibitor-1 (PAI-1) expression in endothelial cells by TNF was also inhibited by genistein (109) while resveratrol (1), with a potent suppressive effect of TNFmediated ICAM-1 and VCAM-1 expression, is reported for its PTK inhibitory activity (110). PTK inhibition is thus an important anti-inflammatory target site and may account for the anti-inflammatory activity of various non-selective kinase inhibitors such as many flavonoids. Unfortunately, PTK inhibitors have been shown to enhance or suppress the TNF-mediated adhesion molecules expression depending on the concentration used and cell types (91) and hence further research is required to clarify the potential of this therapeutic target. As with TNF production and cytotoxicity, elevation of the intracellular cAMP level in cells has been associated with suppressed expression of cell adhesion molecules by TNF which has recently been shown to be due to inhibition of NF- $\kappa B$ mediated gene expression (111). The demonstration that forskolin $(74$, tested at $5 \mu \mathrm{M})$, and $\mathrm{PGE}_{2}(0.1-10 \mu \mathrm{M})$ were able to lower the TNF-mediated lymphocyte adhesion and upregulation of adhesion molecules (ICAM-1 and VCAM-1) expression in smooth muscle cells (112) was thus expected. PGE $_{2}$ and prostacyclin are also known to inhibit the TNF-mediated cytokines production (113).

Other compounds with suppressive effects on adhesion molecules expression include the anti-inflammatory diterpene, andrographolide $(\mathbf{7 1} ; 1.8-16.7 \mu \mathrm{g} / \mathrm{ml})$, which has been shown to inhibit ICAM-1 expression and endothelial-monocyte adhesion (114); bicalein inhibiting ICAM-1 ( IC $_{50} 40 \mu \mathrm{M}$ ) and ELAM1 ( $\mathrm{IC}_{50} 23 \mathrm{MM}$ ) expression (90) and also inhibition of TNFmediated expression of plasminogen activator inhibitor-1 (115); rooperol (72; 2.5-20 $\mu \mathrm{M})$ inhibiting VCAM-1 mRNA expression (116); retinoic acid inhibiting TNF-induced cell surface expression of VCAM-1 (117) and shikonin (73) inhibiting the $\alpha_{v} \beta_{3}$ integrin-dependent endothelial network formation in vitro and angiogenesis in vivo (118).

A very recent study on the cardioprotective effects of the polyphenolic components of red wine has demonstrated that resveratrol (1) inhibits not only TNF production but also the TNFinduced expression of tissue factor in endothelial cells (119). DHA and EPA suppress the TNF-induced production of another proinflammatory cytokine IL-6 in endothelial cells (120) while quercetin inhibits IL-8 and monocyte chemoattractant protein1 production in synovial cells (121). The TNF-induced induction of inducible-nitric oxide synthase (iNOS) and the subsequent NO production have been shown to be inhibited by aspirin in vascular smooth muscle cells (122) while similar inhibitory effects were reported for curcumin (3) (123), quercetin (124), caffeine and theophyline (125), dehydrocostus lactone (53) (20), cyclosporin A (140), DHA and EPA (127), (128), and also rooperol (72) with inhibitory effect on iNOS mRNA (116).

\section{Conclusions}

While the complete biochemical pathways for TNF production and action have yet to be fully elucidated, several target sites have been identified. Of these targets, the transcription factor, $\mathrm{NF}-\kappa \mathrm{B}$ is most interesting as NF- $\kappa \mathrm{B}$ regulates TNF production and, in turn, TNF regulates NF- $\kappa \mathrm{B}$ reciprocally to produce its biological effects. A number of natural products widely known for their anti-inflammatory activities has been shown to modulate TNF release and function through suppression of $\mathrm{NF}-\kappa \mathrm{B}$ activation. Other targets for natural products that have been demonstrated to inhibit TNF production are kinase enzymes and the cAMP system. There appears to be very few compounds inhibiting TNF production/function at the posttranslational level and the highly demanded TNF receptor antagonist is still not available.

\section{References}

1 Vassalli P. The pathology of tumor necrosis factors. Annu. Rev. Immunol. 1992; 10: $411-52$

2 Tracy KJ, Cerami A. Tumor necrosis factor - a pliotropic cytokine and therapeutic agent. Annu. Rev. Med. 1994; 45: 491 - 3

3 Bevilacqua MP, Nelson RM, Mannori GM, Cecconi O. Endothelialleukocyte adhesion molecules in human disease. Annu. Rev. Med. 1994; 45: $361-78$

4 Argiles JM, Lopez-Soriano J, Busquets S, Lopez-Soriano FJ. Journey from cachexia to obesity by TNF. FASEB J. 1997; 11: $743-51$ 
5 Garcia-Martinez C, Costelli P, Lopez-Soriano FJ, Argiles JM. Is TNF really involved in cachexia? Cancer Invest. 1997; 15: 47-54

6 Murphy K, Haudek SB, Thompson M, Giroir BP. Molecular biology of septic shock. New horizons. Sci. Practice Acute Med. 1998; 6 : $181-93$

7 Medana IM, Hunt NH, Chaudhri G. TNF expression in the brain during fatal murine cerebral malaria - Evidence for production by microglia and astrocytes. Am. J. Pathol. 1997; 150: 1473-86

8 Bjornsdottir US, Cypcar DM. Asthma: an inflammatory mediator soup. Allergy 1999; 54: 55-61

9 Sekut L, Connolly KM. Pathophysiology and regulation of TNF in inflammation. Drug News Perspectives 1996; 9: 261 -9

10 Young PR. Pharmacological modulation of cytokine action and production through signaling pathways. Cytokine \& Growth Factor Rev. 1999; 9: 239-57

11 Eugui EM, Delustro B, Rouhafza S, Ilnicka M, Lee SW, Wilhelm R, Allison AA. Some antioxidants inhibit, in a coordinate fashion, the production of TNF, IL- $1 \beta$, and IL- 6 by human peripheral-blood mononuclear cells. International Immunol. 1994; 6: 409-22

12 Abe Y, Hashimoto S, Horie T. Curcumin inhibition of inflammatory cytokine production by human peripheral blood monocytes and alveolar macrophages. Pharmacol. Res. 1999; 39: 41 -7

13 Mrowietz U, Jessat H, Schwarz A, Schwarz T. Anthralin (Dithranol) in vitro inhibits human monocytes to secrete IL-6, IL-8 and TNF- $\alpha$, but not IL-1. Br. J. Dermatol. 1997; 136: $542-7$

14 Li ZY, Davis GS, Mohr C, Nain M, Gemsa D. Inhibition of LPS-induced TNF by colchicine and other microtubule disrupting drugs. Immunobiology 1996; 195: 624-39

15 Ju DW, Jheng QY, Cao XT, Fang J, Wang HB. Esculentoside A inhibits TNF, IL-1 and IL-6 production induced by LPS in mice. Pharmacology 1998; 56: 187-95

16 Shinji H, Akagawa KS, Yoshida T. Cytochalasin-D inhibits LPS-induced TNF production in macrophages. J. Leukocyte Biol. 1993; 54: $336-42$

17 Moon EY, Rhee DK, Pyo S. In vitro suppressive effect of aflatoxin $\mathrm{B}-1$ on murine peritoneal macrophage functions. Toxicology 1999; 133: $171-9$

18 Habtemariam S. Extract of corn silk (stigma of Zea mays) inhibits the TNF and bacterial lipopolysaccharide-induced cell adhesion and ICAM-1 expression. Planta Med. 1998; 64: 314-8

19 Wadsworth TL, Koop DR. Effects of the wine polyphenolics quercetin and resveratrol on pro-inflammatory cytokine expression in RAW 264.7 macrophages. Biochem. Pharmacol. 1999; 57: $941-9$

20 Lee HJ, Kim NY, Jang MK, Son HJ, Kim KM, Sohn DH, et al. A sesquiterpene, dehydrocostus lactone, inhibits the expression of inducible nitric oxide synthase and TNF in LPS-activated macrophages. Planta Med. 1999; 65: 104-8

21 Kawada N, Seki S, Inoue M, Kuroki T. Effect of antioxidants, resveratrol, quercetin, and $\mathrm{N}$-acetylcysteine, on the functions of cultured rat hepatic stellate cells and Kupffer cells. Hepatology 1998; 27: $1265-74$

22 Shames BD, Selzman CH, Pulido EJ, Meng XZ, Meldrum DR, McIntyre RC, Harken AH, Banerjee A. LPS-induced NF- $\kappa$ B activation and TNF release in human monocytes are protein tyrosine kinase dependent and protein kinase C independent. J. Surg. Res. 1999; 83: $69-74$

23 Schreiber S. Activation of NF- $\kappa \mathrm{B}$ as a target for anti-inflammatory therapy. Gut 1999; 44: 309-10

24 Siebenlist U, Franzo G, Brown K. Structure, regulation and function of NF- $\kappa$ B. Annu. Rev. Cell Biol. 1994; 10: 405-55

25 Vittimberga FJ, McDade TP, Perugini RA, Callery MP. Sodium salicylate inhibits macrophage TNF production and alters MAPK activation. J. Surg. Res. 1999; 84: 143 -9

26 Shackelford RE, Alford PB, Xue Y, Thai SF, Adams DO, Pizzo S. Aspirin inhibits TNF gene expression in murine tissue macrophages. Mol. Pharmacol. 1997; 52: 421 -9
27 Tsai SH, Liang YC, LinShiau SY, Lin JK. Suppression of TNF-mediated NF- $\kappa \mathrm{B}$ activity by myricetin and other flavonoids through downregulation the activity of IKK in ECV304 cells. J. Cellular Biochem. 1999; 74: 606-15

28 Xu YX, Pindolia KR, Janakiraman N, Chapman RA, Gautam SC. Curcumin inhibits Il1- $\alpha$ and TNF induction of AP-1 and NF- $\kappa$ B DNA-binding activity in bone marrow stromal cells. Hematology Mol. Hematology 1998; 11: 49-62

29 Yang FG, DeViller WJS, McClain CJ, Varilek GW. The green tea polyphenol, EGCG inhibits LPS-mediated NF- $\kappa \mathrm{B}$ activation and TNF- $\alpha$ production in the macrophage cell line, RAW264.7. FASEB J. 1998; 12: S258

30 Page S, Fisher C, Baumgartner B, Haas M, Kreusel U, Loidl G, Hayan $\mathrm{M}$, Zieglerheitbrock HWL. 4-Hydroxynonenal prevents NF- $\mathrm{KB}$ activation and TNF expression by inhibiting I $\kappa \mathrm{B}$ phosphorylation and subsequent proteolysis. J. Biol. Chem. 1999; 274: 11611 - 8

31 Singh S, Natarajan K, Aggarwal BB. Capsaicin (8-methyl- $N$-vanillyl-6-nonenamide) is a potent inhibitor of nuclear transcription factor- $\kappa$ B activation by diverse agents. J. Immunol. 1996; 157: $4412-20$

32 Yu R, Park JW, Kurata T, Erickson KL. Modulation of select immune responses by dietary capsaicin. Int. J. Vitam. Nutr. Res. 1998; 68: 114-9

33 Roy S, Cain KJ, Chapin RB, Charboneau RG, Barke RA. Morphine modulates NF- $\kappa$ B activation in macrophages. Biochem. Biophys. Res. Commun. 1998; 245: $392-6$

34 Bencsics A, Elenkov IJ, Vizi ES. J. Effect of morphine on lipopolysaccharide-induced TNF- $\alpha$ production in vitro: Involvement of the sympathetic nervous system. Neuroimmunology 1997; 73: $1-6$

35 Vayssier M, Favatier F, Pinot F, Bachelet N, Polla BS. Tobacco smoke induced coordinate activation of HSF and inhibition of NF $\kappa \mathrm{B}$ in human monocytes: Effects of TNF $\alpha$ release. Biochem. Biophys. Res. Commun. 1999; 252: 249-56

36 Madretsma GS, Donze GJ, VanDijk APM, Tak CJAM, Wilson JHP, Zijlstra FJ. Nicotine inhibits the in vitro production of IL-2 and TNF- $\alpha$ by human mononuclear cells. Immunopharmacology 1996; 35: $47-51$

37 Pyatt DW, Stillman WS, Irons RD. Hydroquinone, a reactive metabolite of benzene, inhibits NF- $\kappa \mathrm{B}$ in primary human $\mathrm{CD} 4^{+} \mathrm{T}$ lymphocytes. Toxicol. Appl. Pharmacol. 1998; 149: 178-84

38 Siegmund B, Eigler A, Moeller J, Greten TF, Hartmann G, Endres S. Suppression of TNF- $\alpha$ production by interleukin- 10 is enhanced by cAMP-elevating agents. Eur. J. Pharmacol. 1997; 321: 231 -9

39 Wang LZ, Liu YQ Cui YH, Zhu FH, Wang BS, Lun N. Effects of dexamethasone, cyprohepatidine, anisodamine, and dinoprostone on TNF production in endotoxic shock. Acta Pharmacol. Sin. 1999; 20: $171-4$

40 Zhang LM, Castresana MR, Shaker IJ, Dalton ML, Leeper-Woodford SK, Newman WH. Increased intracellular cyclic adenosine $3^{\prime}, 5^{\prime}$-monophosphate inhibits release of TNF- $\alpha$ from human vascular tissue and cultured smooth muscle cells. Critical Care Med. 1997; 25: $1855-61$

41 Schudt C, Tenor H, Hatzelmann A. PDE isoenzymes as targets for antiasthma drugs. Eur. Resp. J. 1995; 8: 1179-83

42 Entzian P, Bitter-Suermann S, Burdon D, Ernst M, Schlaak M, Zabel P. Differences in the anti-inflammatory effects of theophylline and pentoxifylline: important for the development of asthma therapy? Allergy 1998; 53: 749-54

43 Manthey JA, Grhmann K, Montanari A, Ash K, Manthey CL. Polymethoxylated flavones derived from citrus suppress TNF- $\alpha$ expression by human monocytes. J. Nat. Prod. 1999; 62: 441 - 4

44 Cho JY, Park J, Yoo ES, Yoshikawa K, Baik KU, Lee J, Park MH. Inhibitory effect of lignans from the rhizomes of Coptis japonica var. dissecta on TNF production in lipopolysaccharide-stimulated RAW264.7 cells. Arch. Pharmacal Res. 1998; 21: $12-6$ 
45 Chae SH, Kim PS, Cho JY, Park JS, Lee JH, Yoo ES et al. Isolation of inhibitory compounds on TNF production from Magnolia fargeslii. Arch. Pharmacal Res. 1998; 21: 67-9

46 Kawaguchi K, Kikuchi S, Hasegawa H, Maruyama H, Morita H, Kumazawa Y. Suppression of lipopolysaccharide-induced TNF release and liver injury in mice by naringin. Eur. J. Pharmacol. 1999; 368: $245-50$

47 Fujiki H, Suganuma M, Okabe S, Sueoka N, Komori A, Sueoka E, et al. Cancer inhibition by green tea. Mutat. Res. Fund. Mol. Mech. Mutagenesis 1998; 402: 307-10

48 Nomura T, Hano Y, Aida M. Isoprenoid-substituted flavonoids from Artocarpus plants (Moraceae). Heterocycles 1998; 47: 1179-205

49 Zi XL, Mukhater H, Agarwal R. Novel cancer chemopreventive effects of a flavonoid antioxidant silymarin: Inhibition of mRNA expression of an endogenous tumor promoter TNF- $\alpha$. Biochem. Biophys. Res. Commun. 1997; 239: 334-9

50 Sheng CY, Gao WY, Guo ZR, He LX. Anisodamine restores bowel circulation in burn shock. Burns 1997; 23: $142-6$

51 Maruyama N, Kakuta Y, Yamauchi K, Ohkawara Y, Aizawa T, Nara $\mathrm{M}$, et al. Quinine inhibits production of tumour necrosis factor- $\alpha$ from human alveolar macrophages. Am. J. Resp. Cell Mol. Biol. 1994; 10: $514-20$

52 Onai N, Tsunokawa Y, Suda M, Watanabe N, Nakamura K, Sugimoto Y, Kobayashi Y. Inhibitory effects of bisbenzylisoquinoline alkaloids on induction of proinflammatory cytokines, interleukin-10 and TNF. Plnata Med. 1995; 61: 497-501

53 Rao P, Falk LA, Dougherty SF, Sawada T, Pluznik DH. Colchicine down-regulates lipopolysaccharide-induced granulocyte-macrophage colony-stimulating factor production in murine macrophages. J. Immunol. 1997; 159: 3531 -9

54 Cho JY, Park JS, Yoo ES, Baik KU, Jung JH, Lee JS, Park MH. Inhibitory effect of sesquiterpene lactones from Saussurea lappa on TNF production in murine macrophage-like cells. Planta Med. 1998; 64: $594-7$

55 Endres S, Ghorbani R, Kelley VE, Georgilis K, Lonnemann G, VanDer-Meer JWM, et al. The effect of dietary supplementation with $\mathrm{N}-3$ poly-unsaturated fatty acid on the synthesis of IL- 1 and TNF by mononuclear cells. New. Eng. J. Med. 1989; 320: 265 - 70

56 Cabral GA, Toney DM, Fischerstenger K, Harrison MP, Marcianocabral F. Anandamide inhibits macrophage-mediated killing of TNF-sensitive cells. Life Sci. 1995; 56: 2065- 72

57 Hase K, Xiong QB, Basnet P, Namura T, Kadota S. Inhibitory effect of tetrahydrowertianolin on TNF-dependent hepatic apoptosis in mice. Biochem. Pharmacol. 1999; 57: 1431 - 7

58 Garcia JEL, Rodrriguez FM, Lopez AJ, Salgado MJG. De-Cabo MRM, Losada JP, et al. Effect of cyclosporin A on inflammatory cytokine production by human alveolar macrophages. Resp. Med. 1998; 92: $722-8$

59 Mazzucco CE, Warr G. Trichodimerol (EMS-182123) inhibits lipopolysaccharide-induced eicosanoid secretion in THP-1 human monocytic cells. J. Leukocyte Biol. 1996; 60: 271-7

60 Shapira L, Soskoline WA, Houri Y, Barak V, Halabi A, Stabholz A. Protection against endotoxic shock and lipopolysaccharide-induced local inflammation by tetracycline: Correlation with inhibition of cytokine secretion. Infect. Immun. 1996; 64: 825-8

61 Shapira L, Houri Y, Barak V, Soskoline WA, Halabi A, Stabholz A. Tetracycline inhibits porphyromonas gingivalis lipopolysaccharide-induced lesions in vivo and TNF processing in vitro. J. Periodental Res. 1997; 32: $183-8$

62 Zheng ZM, Specter SC. $\delta^{9}$-Tetrahydrocannabinol suppresses TNF maturation and secretion but not its transcription in mouse macrophages. Int. J. Immunopharmacol. 1996; 18: 53-68

63 Schultz MJ, Speelman P, Zaat S, VanDeventer SJH, Vander-Pool T. Erythromycin inhibits TNF and interleukin-6 production induced by heat-killed Streptococcus pneumoniae in whole blood. Antimicrob. Agents Chemother. 1998; 42: 1605-9
64 Natarajan K, Natarjan K, Manna SK, Chaturvedi MM, Aggarwal BB. Protein tyrosine kinase inhibitors block TNF-induced activation of $\mathrm{NF}-\kappa \mathrm{B}$, degradation of $\mathrm{I} \kappa \mathrm{B} \alpha$, nuclear translocation of p65, and subsequent gene expression. Arch. Biochem. Biophys. 1998; 352: 59 70

65 Morris PE, Olmstead LE, Howardcarroll AE, Dickens GR, Goltz ML, Countneyshapiro $\mathrm{C}$, et al. In vitro and in vivo effects of genistein on murine alveolar macrophage TNF- $\alpha$ production. Inflammation 1999; 23: $231-9$

66 Ruetten H, Thiemermann C. Effects of tyrophostins and genistein on the circulatory failure and organ dysfunction caused by endotoxin in the rat: a possible role for protein tyrosine kinase. Br. J. Pharmacol. 1997; 122: 59-70

67 Van Ostade X. Protein engineering of TNF and lyphotoxin. Drug News Perspectives 1995; 8: 69-79

68 Habtemariam S. Modulation of TNF-induced cytotoxicity by polyphenols. Phytotherapy Res. 1997; 11: 227-30

69 Oddonnell VB, Spycher S, Azzi A. Involvement of oxidants and oxidant-generating enzyme(s) in TNF-mediated apoptosis - Role for lipoxygenase pathway but not mitochondrial respiratorychain. Biochem. J. 1995; 310: $133-41$

70 Habtemariam S. Flavonoids as inhibitors or enhancers of the cytotoxicity of TNF in L-929 tumor cells. J. Nat. Prod. 1997; 60: $775-8$

71 Sumitomo M, Tachilbabna M, Nakashima J, Murai M, Miyajima A, Kimura F, et al. An essential role for nuclear factor $\kappa B$ in preventing TNF-induced cell death in prostate cancer cells. J. Urol. 1999; 161: $674-9$

$72 \mathrm{Xu}$ Y, Bialik S, Jones BE, Iimuro Y, Kitsis RN, Srinivasan A, et al. NF- $\kappa B$ inactivation converts a hepatocyte cell line TNF response from proliferation to apoptosis. Am. J. Physiol.-Cell Physiol. 1998; 44: C1058-66

73 Mcdade TP, Perugini RA, Vittimberga FJ, Carrigan RC, Callery MP. Salicylates inhibit NF- $\mathrm{KB}$ activation and enhance TNF-induced apoptosis in human pancreatic cancer cells. J. Sug. Res. 1999; 83: $56-61$

74 Ward C, Chilvers ER, Lawson MF, Pryde JG, Fujihara S, Farrow SN, et al. NF- $\kappa B$ activation is a critical regulator of human granulocyte apoptosis in vitro. J. Biol. Chem. 1999; 274: 4309-18

75 Hehner SP, Heinrich M, Bork PM, Vogt M, Ratter F, Lehmann V, et al. Sesquiterpene lactones specifically inhibit activation of NF- $\kappa \mathrm{B}$ by preventing the degradation of $\mathrm{I} \kappa \mathrm{B} \alpha$ and $\mathrm{I} \kappa \mathrm{B} \beta$. J. Biol. Chem. 1998; 273: $1288-97$

76 Sueoka E, Sueoka N, Kai Y, Okabe S, Suganum M, Kanematsu K, et al. Anticancer activity of morphine and its synthetic derivative, KT-90, mediated through apoptosis and inhibition of NF- $\mathrm{KB}$ activation. Biochem. Biophys. Res. Commun. 1998; 252: 566 - 70

77 Sasaki CY, Patek PQ. The involvement of protein-tyrosine kinaseactivity in TNF resistance mechanism. Proc. Soc. Exp. Biol. Med. 1995; 210: $25-32$

78 Niwa M, Hara A, Kanamori Y, Matsuno H, Kozawa O, Yoshimi N, et al. Inhibition of TNF-induced neutrophil apoptosis by cyclic AMP: involvement of caspase cascade. Eur. J. Pharmacol. 1999; 371: 59-67

79 Brekke OL, Espevic T, Bjerve KS. Butylated hydroxyanisole inhibits tumour necrosis factor-induced cytotoxicity and arachidonic acid release. Lipids 1994; 29: 91 - 102

80 Hofsli E, Waage A. Effect of pyridoxine on TNF activities in vitro. Biotherapy 1992; 5: 285-90

81 Hughes TK, Fulep E. Effects of retinoic acid (vitamin A) on TNF cytolytic action. Biochem. Biophys. Res. Commun. 1995; 206: 223-9

82 Li JX, Shi Q Xiong QB, Prasain JK, Tezuka Y, Hareyama T, et al. Tribulusamide $A$ and $B$, new hepatoprotective lignanamides from the fruits of Tribulus terrestris: Indications of cytoprotective activity in murine hepatocyte culture. Planta Med. 1998; 64: 628 31 
83 Matsuda H, Ninomiya K, Morikawa T, Yoshikawa M. Inhibitory effect and action mechanism of sesquiterpenes from Zedoariae rhizoma on D-galactosamine/lipopolysaccharide-induced liver injury. Bioorg. Med. Chem. Lett. 1998; 8: 339-44

${ }^{84}$ Hase K, Li JX, Basnet P, Xiong QB, Takamura S, Namba T, et al. Hepatoprotective principles of Swertia japonica on D-galactosamine/lipopolysaccharide-induced liver injury in mice. Chem. Pharm. Bull. 1997; 45: $1823-7$

85 Leist M, Ganter F, Jilg S, Wendel A. Activation of the 55-kda receptor is necessary and sufficient for TNF-induced liver-failure, hepatocyte apoptosis, and nitrate release. J. Immunol. 1995; 154: $1307-16$

86 Schleimer RP, Rutledge BK. Cultured human vascular endothelial cells acquire adhesiveness for neutrophils after stimulation with interleukin-1, endotoxin and tumour promoting phorbol diesters. J. Immunol. 1986; 136: 649-54

87 Murase T, Kume N, Hase T, Shibuya Y, Tokimitsu I, Kita T. Gallates inhibit cytokine-induced nuclear translocation of NF- $\kappa \mathrm{B}$ and expression of leukocyte adhesion molecules in vascular endothelia cells. Atherosclerosis Thrombosis Vascular Biol. 1999; 19: 1412 20

88 Kumar A, Dhawan S, Agganwal BB. Emodin (3-methyl-1,6,8-trihydroxyanthraquinone) inhibits TNF-induced NF- $\kappa B$ activation, I $\kappa$ B degradation, and expression of cell surface adhesion proteins in human vascular endothelial cells. Oncogene 1988; 17: 913-8

89 Weber C, Erl W, Pietsch A, Weber PC. Aspirin inhibits NF- $\kappa$ B mobilisation and monocyte adhesion in stimulated human endothelial cells. Circulation 1995; 91: $1914-7$

90 Kimura Y, Matsushita N, Okuda H. Effects of baicalein isolated from Scutellaria baicalensis on interleukin-1 $\beta$ and TNF-induced adhesion molecule expression in cultured human umbilical vein endothelial cells. J. Ethnopharmacol. 1997; 57: 63-7

91 Burke-Gaffney A, Hellwell PG. TNF-induced ICAM-1 expression in human vascular endothelial and lung epithelial cells: Modulation by tyrosine kinase inhibitors. Br. J. Pharmacol. 1996; 119: $1149-58$

92 Chen CC, Rosenbloom CL, Anderson DC, Manning AM. Selective inhibition of E-selectin, VCAM-1, and ICAM-1 expression by inhibition of IKB $\alpha$ phosphorylation. J. Immunol. 1995; 155: 3538-45

93 Pierce JW, Road MA, Ding H, Luscinskas FW, Collins T. Salicylates inhibit I $\mathrm{B} \beta \beta$ phosphorylation, ELAM expression, and neutrophil transmigration. J. Immunol. 1996; 156: 3961 -9

94 Kumar A, Dhawan S, Hardegen NJ, Aggarwal BB. Curcumin (diferuloylmethane) inhibition of TNF-mediated adhesion of monocytes to endothelial cells by suppression of cell surface expression of adhesion molecules and of nuclear factor- $\kappa \mathrm{B}$ activation. Biochem. Pharmacol. 1998; 55: 775-83

95 Gerritsen ME, Carley WW, Ranges GE, Shen CP, Phan SA, Ligon GF, et al. Flavonoids inhibit cytokine-induced endothelial-cell adhesion protein gene-expression. Am. J. Pathol. 1995; 147: 278 92

96 Xu YX, Pindolia KR, Janakiraman N, Noth CJ, Chapman RA, Gautam SC, et al. Curcumin, a compound with anti-inflammatory and anti-oxidant properties, down-regulates chemokine expression in bone marrow stromal cells. Exp. Heamatol. 1997; 25: 413-22

97 Bork PM, Bacher S, Schmitz ML, Kaspers U, Heinrich M. Hypericin as a non-antioxidant inhibitor of NF- $\kappa$ B. Planta Med. 1999; 65: $297-300$

98 Breton JJ, Chabot-Fletcher MC. The natural product hymenialdisine inhibits interleukin-8 production in U937 cells by inhibition of NF- $\kappa$ B. J. Pharmacol. Exp. Ther. 1997; 282: 459-66

99 Qiu DM, Zhao GH, Aoki Y, Shi LF, Uyei A, Nazarian S. Immunosuppressant PG490 (triptolide) inhibits T-cell interleukin-2 expression at the level of purine-box/nuclear factor of activated T-cells and NF- $\kappa B$ transcriptional activation. J. Biol. Chem. 1999; 274: $13443-50$
100 Sato M, Miyazaki T, Kambe F, Maeda K, Seo H. Quercetin, a bioflavonoid, inhibits the induction of interleukin-8 and monocyte chemoattractant protein-1 expression by TNF in cultured human synovial cells. J. Rheumatol. 1997; 24: 1680-4

${ }^{101}$ Bierhaus A, Zhang YM, Quehenberger P, Luther T, Haase M, Muller M, Mackman N, Ziegler R, Narworth PP. The dietary pigment curcumin reduces endothelial tissue factor gene expression by inhibiting binding of AP-1 to the DNA and activation of NF- $\kappa \mathrm{B}$. Thromb. Haemostasis 1997; 77: 772-82

102 Khalfoun B, Thibault G, Lebranchu Y. Docosahexaenoic acid and eicosahexaenoic acids inhibit in vitro human lymphocyte-endothelial cell adhesion. Transplantation 1996; 62: 1649-57

${ }^{103}$ Carluccio MA, Massaro M, Bonfrate C, Siculella L, Maffia M, Nicolardi G. Oleic acid inhibits endothelial activation - A direct vascular antiatherogenic mechanism of a nutritional component in the mediterranean diet. Arteriosclerosis thrombosis vascular biol. 1999; 19: 220-8

104 Decateriona R, Cybulsky MI, Clinton SK, Gimbrone MA, Libby P. The $\omega-3$ fatty acid docosahexaenoate reduces cytokine-induced expression of proatherogenic and proinflammatory proteins in human endothelial cells. Arteriosclerosis Thrombosis 1994; 14: $1829-36$

${ }^{105}$ Chaturvedi MM, Kumar A, Darney BG, Chainy GBN, Agarwal S, Aggarwal BB. Sanguinarine (pseudochelerythrine) is a potent inhibitor of NF- $\kappa \mathrm{B}$ activation, i $\mathrm{B} \mathrm{B} \alpha$ phosphorylation, and degradation. J. Biol. Chem. 1997; 272: 30129-34

${ }^{106}$ Lyss G, Knorre A, Schmidt TJ, Pahl HL, Merfort I. The anti-inflammatory sesquiterpene lactone helenalin inhibits the transcription factor NF- $\mathrm{KB}$ by directly targeting p65. J. Biol. Chem. 1998; 273: $33508-16$

107 May MJ, Wheeler-Jones PCD, Pearson JD. Effects of protein tyrosine kinase inhibitors on cytokine-induced adhesion molecule expression by human umbilical vein endothelial cells. Br. J. Pharmacol. 1996; 118: 1761 - 71

108 Weber C, Negrescu E, Pietsch A, Frankenberger M, Zieglerheitbrock HWL, Sies W, et al. Inhibitors of protein-tyrosine kinase suppress TNF-stimulated induction of endotrhelial cell adhesion molecules. J. Immunol. 1995; 155: 445-51

${ }^{109}$ Vanhinsbergh VWM, Vermeer M, Koolwijk P, Grimbergen J, Kooistra T. Genistein reduces TNF induced plasminogen activator inhibitor-1 transcription but not urokinase expression in human endothelial cells. Blood 1994; 84: 2984-91

${ }^{110}$ Ferrero ME, Bertelli AAE, Fulgenzi A, Pellegatta F, Corsi M, Bonfrate $\mathrm{M}$, et al. Activity in vitro of resveratrol on granulocyte and monocyte adhesion to endotheliam. Am. J. Clin. Nutr. 1998; 68: $1208-14$

111 Oliver V, Parry GCN, Cobb RR, DeProst D, Mackman N. Elevated cAMP inhibits NF $\kappa \mathrm{B}$-mediated transcription in human monocyte cells and endothelial cells. J. Biol. Chem. 1996; 271: 20828 - 35

112 Panettieri RA, Lazaar AL, Albelda SM. Activation of cAMP-dependent pathways in human airway smooth-muscle cells inhibits the TNF-induced ICAM-1 and VCAM-1 expression and lymphocyte adhesion. J. Immunol. 1995; 154: 2358-65

113 Kitahara M, Mori T. Prostacyclin and prostaglandin E2 inhibit proinflammatory cytokine-induced MCSF production in cultured human glomerular mesangial cells. Nephrology 1997; 3: 541 - 7

114 Habtemariam S. Andrographolide inhibits the TNFI-induced upregulation of ICAM-1 expression and endothelial-monocyte adhesion. Phytotherapy Res. 1998; 12: 37-40

115 Kimura Y, Okuda H, Hayashi KY, Matsushita N. Effects of baicalein isolated from roots of Scutellaria baicalensis Georgi on interleukin- $1 \beta$ and TNF-induced tissue-type plasminogen activator and plasminogen activator inhibitor-1 production in cultured human umbilical vein endothelial cells. Phytotherapy Res. 1997; 11: $363-7$ 
116 Bereta J, Bereta M, Allison AC, Kruger PB, Koj A. Inhibitory effect of dicatechol rooperol on VCAM-1 and iNOS expression in cytokine-stimulated endothelium. Life Sciences 1996; 60: 325 - 34

117 Gille J, Paxton LLL, Lawley TJ, Caughman SW, Swerlick RA. Retinoic acid inhibits the regulated expression of VCAM- 1 by cultured dermal microvascular endothelial cell. J. Clin. Invest. 1997; 99: $492-500$

118 Hisa T, Kimura Y, Takada K, Suzuki F, Takigawa M. Shikonin, an ingredient of Lithospermum erythrorhizon, inhibits angiogenesis in vivo and in vitro. Anticancer Res. 1998; 18: 783-90

119 Pendurthi UR, Williams JT, Rao LVM. Resveratrol, a polyphenolic compound found in wine, inhibits tissue factor expression in vascular cells - A possible mechanism for the cardiovascular benefits associated with moderate consumption of wine. Arteriosclerosis, Thrombosis Vascular Biol. 1999; 19: 419-26

120 Khalfoun B, Thibault F, Watier H, Bardos P, Lebrachu Y. Docosahexaenoic and eicosapentaenoic acids inhibit in vitro human endothelial cell production of interleukin-6. Adv. Exp. Med. Biol. 1997; 400: $589-97$

121 Sato M, Miyazaki T, Kambe F, Maeda K, Seo H. Quercetin, a bioflavonoid, inhibits the induction of interleukin-8 and monocyte chemoattractant protein-1 expression by TNF in cultured human synovial cells. J. Rheumatol. 1997; 24: 1680-4

122 Katsuyama K, Shichiri M, Kato H, Imai T, Marumo F, Hirata Y. Differential inhibitory actions by glucocorticoid and aspirin on cytokine-induced nitric oxide production in vascular smooth muscle cells. Endocrinology 1999; 140: 2183 - 90

${ }^{123}$ Chan MMY, Huang HI, Fenton MR, Fong D. In vitro inhibition of nitric oxide synthase gene expression by curcumin, a cancer preventive natural product with anti-inflammatory properties. Biochem. Pharmacol. 1998; 55: 1955-62

${ }^{124}$ Jeyarajah DR, Kielar M, Penfield J, Lu CY. Docosahexaenoic acid, a component of fish oil, inhibits nitric oxide production in vitro. J. Surg. Res. 1999; 83: $147-50$

125 Bereta M, Bereta J, Georgoff I, Coffman FD, Cohen S, Cohen MC. Methylxanthins and calcium-mobilizing agents inhibit the expression of cytokine-inducible nitric oxide synthase and vascular cell adhesion molecule- 1 in murine microvascular endothelial cells. Exp. Cell Res. 1994; 212: 230-42

${ }^{126}$ Fast DJ, Lynch RC, Leu RW. Cyclosporin A inhibits nitric oxide production by L929 cells in response to TNF and interferon- $\gamma$. J. Interferon Res. 1993; 13: 235-40

${ }^{127}$ Jeyarajah DR, Kielar M, Penfield J, Lu CY. Docosahexaenoic acid, a compound of fish oil, inhibits nitric oxide production in vitro. J. Sug. Res. 1999; 83: $147-50$

${ }^{128}$ Lu CY, Penfield JG, KhairiDin TA, Sicher SC, Kielar ML, Vazquez MA, Che L. Docosahexaenoic acid, a constituent of fetal and neonatal serum, inhibits nitric oxide production by murine macrophages stimulated by IFN- $\gamma$ plus LPS, or by IFN- $\gamma$ plus Listeria monocytogenes. J. Reprod. Immunol. 1998; 38: 31 -53

\section{Dr. Solomon Habtemariam}

School of Chemical and Life Sciences

The University of Greenwich

Wellington Street

Woolwich

London SE18 6PF

UK

E-mail: S.Habtemariam@gre.ac.uk

Fax: +44(0)208-331-8305 